\title{
Pengaruh Penggunaan Bungkil Inti Sawit, Minyak Sawit, dan Bungkil Inti Sawit Fermentasi Pengganti Ampas Tahu dalam Ransum terhadap Pertumbuhan Kambing Nubian Dara
}

\author{
Effect of Feeding Palm Kernel Cake, Palm Oil and Fermented Palm Kernel Cake Replacing \\ Solid by-product of Tofu on Growth of Nubian Doeling Goat
}

Suhendro, Hidayat, dan T. Akbarillah

Jurusan Peternakan, Fakultas Pertanian, Universitas Bengkulu

Jl. WR. Supratman, Kandang Limun, Bengkulu

Email : hendroakses@gmail.com

\begin{abstract}
This research was conducted to evaluate the growth response of young Nubian fed diet containing palm kernel cake (PKC) as a source of protein, original PKC, fermented PKC, or palm oil to replace solid by-product of tofu. The research design used was the Latin Square Designs, consisting of 2 squares with 4 treatments $(2 \times 4 \times 4)$. The animal used were 8 heads of six-month-old Nubian doeling goats weighing between $20-25 \mathrm{~kg}$. The treatments used were four differnt concentrates, original palm kernel cake (P1), original palm kernel cake and palm oil (P2), fermented palm kernel cake (P3), and solid by-product of tofu (P4). Variables measured were feed intake (dry matter, organic matter, and protein intake), and weight gain. Result showed that the treatment was not significant $(\mathrm{P}>0.05)$ on forage dry matter intake, forage organic matter intake, forage crude protein intake and total of crude protein intake. The $\mathrm{P} 4$ treatment was significantly different $(\mathrm{P}<0.01)$ on concentrate dry matter intake, concentrate organic matter intake and concentrate crude protein intake. It is known that solid by-product tofu was more preferable than that of palm kernel cake concentrate. The results of this study showed that the treatment had no significant effect on weight gain $(\mathrm{P}>0.05)$. It showed that the gain of P1, P2, P3, and P4 were 70,60, 60, and $40 \mathrm{gram} / \mathrm{head} /$ day respectively. It can be concluded that the use of palm kernel cake concentrate can replace the solid by-product of tofu in the ration without adversely affecting the growth of Nubian goats.
\end{abstract}

Key words: Nubian goat, palm kernel cake, growth

\begin{abstract}
ABSTRAK
Penelitian ini bertujuan untuk mengevaluasi respon pertumbuhan kambing Nubian dara yang menggunakan pakan mengandung bungkil inti sawit sebagai sumber protein, baik bungkil inti sawit asal maupun yang difermentasi, serta penggunaan minyak sawit dalam menggantikan ampas tahu. Rancangan yang digunakan adalah rancangan bujur sangkar latin (RBSL) sebanyak 2 bujur sangkar dengan 4 macam perlakuan $(2 \mathrm{x} 4)$. Ternak yang digunakan sebanyak 8 ekor kambing Nubian berumur 6 bulan dengan berat antara 20-25 kg. Perlakuan yang digunakan adalah pemberian pakan konsentrat yang berbeda, yang terdiri dari bungkil inti sawit segar (P1), bungkil inti sawit segar dan minyak sawit (P2), bungkil sawit fermentasi (P3), dan ampas tahu (P4). Variabel yang diukur adalah konsumsi bahan kering (BK) pakan (hijauan dan konsentrat), konsum bahan organik (BO) pakan (hijauan dan konsentrat, konsumsi protein kasar (hijauan dan konsentrat) dan pertambahan berat badan. Hasil penelitian menunjukkan bahwa perlakuan berpengaruh tidak nyata $(\mathrm{P}>0,05)$ terhadap konsumsi BK hijauan, BO hijauan, PK hijauan dan PK total. Pemberian konsentrat ampas tahu sangat nyata $(\mathrm{P}<0,01)$ lebih disukai dari pada konsentrat berbahan bungkil inti sawit. Rata-rata pertambahan berat menunjukkan bahwa perlakuan berpengaruh tidak nyata, dengan hasil untuk masing-masing perlakuan P1, P2, P3, dan P4 berturut-turut adalah 70, 60, 60, dan 40 gram/ekor/hari. Penggunaan konsentrat BIS, dapat menggantikan ampas tahu dalam ransum tanpa berdampak negatif terhadap pertumbuhan kambing Nubian
\end{abstract}

Kata kunci: Kambing Nubian, bungkil inti sawit, pertumbuhan.

PENDAHULUAN

Pakan merupakan unsur utama yang

harus terpenuhi untuk mencapai produktifitas ternak yang optimal dari potensi genetik ternak tersebut. Selain itu, pertumbuhan ternak yang ideal pada fase 
pertumbuhan akan mempengaruhi kesiapan ternak untuk dikawinkan pertama kali. Oleh karena itu, pemilihan jenis pakan merupakan salah satu upaya untuk meningkatkan laju pertumbuhan dan efisiensi pakan (Murtisari, 2005). Untuk meningkatkan produktivitas kambing diperlukan pakan berkualitas, dengan kandungan nutrisi yang baik dan ketersediaan yang cukup. Agar pertumbuhan kambing dapat optimal, pemberian pakan selain hijauan, juga diberikan pakan penguat berupa konsentrat. Pemberian pakan untuk mendukung produksi ternak seyogyanya menggunakan pakan yang murah, mudah didapatkan, serta tersedia sepanjang tahun. Salah satu pakan alternatif yang dimaksud adalah limbah atau hasil ikutan kebun sawit dan industri pengolahannya, yang berupa

Bungkil inti sawit (BIS) merupakan limbah atau hasil ikutan industri pengolahan kelapa sawit yang ketersediaan sangat berlimpah dan berpotensi sebagai sumber protein bagi ruminansia. Kandungan protein di dalam BIS cukup tinggi, dapat mencapai 21,51\% (Wijianto, 2016) atau 14 - $20 \%$ (Zarei et al., 2012) dan energi metabolis antara 1817-2654 $\mathrm{kkal} / \mathrm{kg}$ (Chanjula et al., 2010). Kandungan protein dari BIS masih dapat ditingkatkan dengan pengolahan secara fermentasi (Mirnawati et al., 2013).

Upaya untuk memperbaiki kualitas gizi, mengurangi, atau menghilangkan pengaruh negatif dari bahan pakan tertentu dapat dilakukan dengan penggunaan mikroorganisme melalui proses fermentasi. Fermentasi juga dapat meningkatkan nilai kecernaan yang dapat menambah rasa dan aroma, serta meningkatkan kandungan vitamin dan mineral. Manfaat pakan fermentasi untuk ternak rumiansia ialah untuk memperbaiki system pencernaan ternak, meningkatkan produksi susu ternak, berat badan ternak cepat bertambah secara alami, serta meningkatkan nafsu makan ternak, daging ternak lebih berisi serta rendah kolesterol (Isnainiyati, 2001).

Selain bungkil inti sawit, minyak sawit diharapkan dapat digunakan untuk memanipulasi mikrobia rumen. Penggunaan minyak sawit diharapkan dapat menekan populasi protozoa rumen dan memberi kesempatan bacteria rumen lebih berkembang. Dalam reviewnya (Davis, 2002) melaporkan bahwa penggunaan minyak nabati (kacang tanah) dapat meningkatkan pertambahan berat badan sapi secara nyata.

Untuk mendapatkan tingkat pertumbuhan optimum ternak, khususnya pertambahan berat badan perlu dilakukan optimalisasi pemanfaatan bungkil inti sawit dan penggunaan minyak sawit. Pertumbuhan lepas sapih merupakan salah satu kriteria yang digunakan sebagai petunjuk efisiensi produksi. Dari penjelasan tersebut diatas maka dilakukan penelitian pengaruh penggunaan bungkil inti sawit, minyak sawit dan fermentasi bungkil inti sawit pengganti ampas tahu dalam ransum terhadap pertumbuhan kambing Nubian dara. 


\section{METODE DAN METODE}

Rancangan percobaan yang digunakan adalah rancangan bujur sangkar latin (RBSL), sebanyak 2 bujur sangkar dengan masing-masing terdiri 4 macam perlakuan $\left(\begin{array}{lllll}2 & x & 4 & x & 4\end{array}\right)$. Ternak yang digunakan sebanyak 8 ekor kambing Nubian dara berumur 6 bulan dengan berat antara 20-25 kg. Perlakuan yang digunakan adalah pemberian pakan yang terdiri dari pakan hijauan dan konsentrat, dengan jenis konsentrat yang berbeda, yaitu bungkil inti sawit segar (P1), bungkil inti sawit segar dan minyak sawit (P2), bungkil inti sawit fermentasi (P3), dan ampas tahu (P4). Sementara hijauan pakan yang digunakan terdiri dari legum Indigofera dan rumput lapangan. Setiap perlakuan berlangsung selama 3 minggu.

Alat yang digunakan selama penelitian adalah kandang, timbangan pakan, timbangan ternak, timbangan analitik, sabit, ember, sapu lidi, tempat minum, gelas ukur, karung, plastik. Bahan yang digunakan antara lain bungkil inti sawit, ampas tahu, probiotik, dan minyak sawit.

Tahapan penelitian meliputi persiapan bahan pakan, fermentasi bungkil inti sawit, persiapan kandang dan ternak kambing. Bungkil inti sawit didapatkan dari pabrik pengolahan stump minyak sawit PT. Agricinal, Bengkulu Utara. Ampas tahu merupakan hasil samping dari pabrik pembuatan tahu, dalam hal ini didatangkan dari produsen tahu di kota Bengkulu.

Fermentasi bungkil inti sawit dengan penggunakan probiotik merk Tangguh.
Penambahan bahan probiotik dengan dosis $10 \mathrm{cc} /$ liter air digunakan untuk $5 \mathrm{~kg}$ BIS. Larutan tersebut kemudian disemprotkan ke semua bagian BIS secara merata, setelah itu pakan konsentrat dimasukan ke dalam kantong-kantong plastik fermentasi sampai tidak ada udara di dalamnya dan didiamkan minimal selama 3 hari. Setelah 3 hari pakan fermentasi siap diberikan ke ternak. Perlakuan BIS dengan penambahan minyak pada ternak, yaitu dengan melakukan dosing diberikan sebanyak $5 \mathrm{ml} / \mathrm{kg}$ berat badan pada setiap awal perlakuan. Hijauan pakan yang digunakan dalam penelitian didapat dari lahan hijauan pakan ternak. Jenis hijauan yang digunakan antara lain rumput lapang dan legum Indigofera. Analisis kadar air (KA), kadar abu, dan kadar protein kasar (PK) dilakukan di Laboratorium di lingkungan Fakultas Pertanian Universitas Bengkulu. Adapun variabel yang diamati selama penelitian meliputi konsumsi pakan, baik hijauan dan konsentrat segar dan bahan kering (BK), bahan organik (BO) dan protein kasar (PK). Pertambahan berat badan dilakukan dengan menimbang ternak pada awal penelitian dan diulang setiap minggu, untuk melihat pertambahan berat badan (PBB) harian ternak.

\section{Analisis data}

Data yang diperoleh dianalisis dengan menggunakan sidik ragam (ANOVA), apabila terdapat berpengaruh nyata maka untuk melihat perbedaan antar perlakuan dilanjutkan dengan Duncant's Multiple Range Test (DMRT) (Astuti, 2007). 


\section{HASIL DAN PEMBAHASAN}

\section{Kandungan nutrisi bahan pakan}

Hasil analisis kandungan nutrisi bahan pakan yang digunakan berupa konsentrat yang terdiri dari bungkil inti sawit (BIS), BIS fermentasi (BIS F) dan ampas tahu serta hijauan ditampilkan pada Tabel 1.

Tabel 1. Kandungan nutrisi bahan pakan yang digunakan atas dasar bahan kering (BK

\begin{tabular}{lccc}
\hline Bahan Pakan & BO & Abu & PK \\
\cline { 2 - 4 } & ----------------- & \% Dasar BK--------------- \\
\hline Bungkil Inti Sawit & 95,17 & 4,83 & 22,23 \\
Bungkil Inti Sawit Fermentasi & 95,46 & 4,54 & 29,84 \\
Ampas tahu & 97,49 & 2,51 & 27,65 \\
Hijauan & 88,77 & 11,22 & 28,97 \\
\hline
\end{tabular}

Berdasarkan hasil analisis laboratorium diketahui bahwa hijauan yang merupakan campuran $\quad 90 \%$ legum Indigofera dan $10 \%$ rumput lapang memiliki kandungan protein kasar dasar BK sebesar 28,97\%, dan konsentrat BIS Segar, BIS Fermentasi dan Ampas tahu berturutturut sebesar 22,23\%, 29,84\% dan 27,65\%.

Kandungan nutrisi bahan organik (BO) atas dasar bahan kering untuk bungkil inti sawit sebesar 95,17\%, bungkil inti sawit yang difermentasi $95,46 \%$, ampas tahu $97,49 \%$ dan hijauan $88,77 \%$.

\section{Konsumsi BK, PK dan BO Hijauan, Konsentrat dan Total}

Rataan konsumsi BK, BO, dan PK dan total pakan pada kambing Nubian tersaji pada Tabel 2.

Hasil penelitian menunjukkan bahwa perlakuan berpengaruh tidak nyata $(\mathrm{P}>0,05)$ terhadap konsumsi BK hijauan, konsumsi BO hijauan, konsumsi PK hijauan dan konsumsi PK total. Konsumsi BK hijauan, BO hijauan dan PK hijauan tidak berbeda nyata disebabkan kambing yang digunakan pada penelitian ini mendapatkan pakan dengan fisik dan komposisi nutrient yang hampir sama dan mempunyai tingkat palatabilitas sama karena kambing diberi hijauan pakan berupa campuran leguminosa (Indigofera) dan rumput lapang yang sama. Parakkasi (1999) menyatakan bahwa faktor pakan yang mempegaruhi konsumsi BK untuk ruminansia antara lain sifat fisik dan komposisi kimia pakan. Tingkat palatabillitas juga berpengaruh terhadap tingkat konsumsi BK ransum, diantaranya dipengaruhi oleh bau, rasa, tekstur, dan suhu (Pond et al., 1995). Demikian juga dengan konsumsi BK total dan konsumsi $\mathrm{PK}$ total tidak berngaruh nyata $(\mathrm{P}>0,05)$. Hal ini diduga kontribusi konsentrat yang dikonsumsi relatif dalam jumlah sedikit dibandingkan dengan konsumsi hijauannya. Sehingga konsumsi konsentrat tidak mempengaruhi konsumsi total pakan BK dan PK total. Menurut Parakkasi (1999) kemampuan ternak ruminansia dalam mengkonsumsi ransum dipengaruhi oleh 
faktor hewan itu sendiri (berat badan, status fisiologik, potensi genetik, tingkat produksi, dan kesehatan ternak, serta umur), faktor pakan dan faktor lingkungan (temperature, kelembaban, curah hujan dan sinar matahari).

Tabel 2. Rataan konsumsi BK, BO, dan PK dan total pakan pada kambing Nubian

\begin{tabular}{lccccc}
\hline \multirow{2}{*}{$\begin{array}{c}\text { Konsumsi } \\
\text { g/ek } / \mathrm{hr})\end{array}$} & $\mathrm{P} 1$ & $\mathrm{P} 2$ & $\mathrm{P} 3$ & $\mathrm{P} 4$ & $\mathrm{P}$ \\
\cline { 2 - 5 } & $1038,65 \pm 184,82$ & $1008,35 \pm 151,50$ & $1063,67 \pm 184,14$ & $982,20 \pm 206,21$ & 0,74 \\
BK hijauan & $65,23^{\mathrm{a}} \pm 49,87$ & $62,63^{\mathrm{a}} \pm 33,92$ & $47,04^{\mathrm{a}} \pm 43,04$ & $302,66^{\mathrm{b}} \pm 18,76$ & 0,00 \\
\hline BK konsentrat & $1103,94 \pm 217,94$ & $1070,88 \pm 156,76$ & $1111,42 \pm 195,76$ & $1284,87 \pm 221,34$ & 0,92 \\
\hline BK total & & & & \\
\hline & & & & & \\
\hline BO hijauan & $849,52 \pm 178,52$ & $817,38 \pm 140,58$ & $879,09 \pm 184,20$ & $813,17 \pm 181,19$ & 0,78 \\
BO konsentrat & $62,10^{\mathrm{a}} \pm 47,46$ & $59,61^{\mathrm{a}} \pm 32,28$ & $45,59^{\mathrm{a}} \pm 41,07$ & $295,06^{\mathrm{b}} \pm 18,29$ & 0,00 \\
\hline BO total & $911,23^{\mathrm{a}} \pm 211,23$ & $876,62^{\mathrm{a}} \pm 138,05$ & $924,68^{\mathrm{a}} \pm 202,12$ & $1108,24^{\mathrm{b}} \pm 194,12$ & 0,03 \\
\hline & & & & \\
\hline PK hijauan & $267,23 \pm 93,23$ & $259,57 \pm 95,40$ & $269,83 \pm 89,70$ & $256,00 \pm 97,45$ & 0,83 \\
PK konsentrat & $18,48^{\mathrm{a}} \pm 17,00$ & $17,74^{\mathrm{a}} \pm 13,48$ & $15,49^{\mathrm{a}} \pm 15,21$ & $73,38^{\mathrm{b}} \pm 29,45$ & 0,00 \\
\hline PK total & $286,12 \pm 96,84$ & $276,31 \pm 93,40$ & $384,87 \pm 82,86$ & $329,38 \pm 111,00$ & 0,09 \\
\hline
\end{tabular}

Keterangan: P1 (BIS Segar), P2 (BIS+Minyak), P3 (BIS Fermentasi) dan P4 (Ampas Tahu). P (Probabiltas)

Sebaliknya, pada konsumsi konsentrat terlihat bahwa perlakuan berpengaruh sangat nyata $(\mathrm{P}<0,01)$ terhadap konsumsi $\mathrm{BK}$ konsentrat, BO konsentrat dan PK konsentrat dan berpengaruh nyata $(\mathrm{P}<0,05)$ terhadap konsumsi BO total. Uji lanjut DMRT menunjukkan bahwa konsumsi BK, BO dan PK konsentrat tidak berbeda pada perlakuan $\mathrm{P} 1, \mathrm{P} 2$, dan $\mathrm{P} 3(\mathrm{P}>0,05)$ namun ketiga perlakuan tersebut nyata lebih rendah dibandingkan $\mathrm{P} 4 \quad(\mathrm{P}<0,05)$. Hal ini dikarenakan konsentrat P1, P2, dan P3 berbahan bungkil inti sawit belum disukai ternak sehingga tidak dikonsumsi dalam jumlah banyak, berbeda dengan P4 yang berbahan ampas tahu dikonsumsi dalam jumlah yang sangat banyak. Pakan konsentrat berbahan bungkil inti sawit tidak disukai ternak karena barangkali teksturnya kering berbeda dengan P4 berupa ampas tahu sangat disukai kambing. Rata-rata konsumsi ampas tahu (P4) tercatat BK sebesar 302,66 g/ekor/hari, BO sebanyak 295,06 g/ekor/hari, dan PK sebanyak 73,38 g/ekor/hari..

Menurut Kearl (1982), kambing lokal di negara-negara berkembang dengan bobot badan $20-25 \mathrm{~kg}$ membutuhkan total protein antara 56-78 gram/ekor/hari. Supriyati dan Haryanto (2015) melaporkan rataan konsumsi protein kasar pada kambing Nubian sebesar 201 gram/ekor/hari. Konsumsi PK untuk semua perlakuan terlihat bahwa rata-rata konsumsi PK telah melebihi dari hasil yang disampaikan oleh Supriyati dan Haryanto (2015). Konsumsi PK yang tinggi pada P4 dikarenakan konsumsi konsentrat (ampas tahu) dikonsumsi lebih banyak. Faktor yang mempengaruhi konsumsi protein pakan adalah konsumsi bahan kering dan kandungan protein dalam pakan. Kualitas ransum akan mempengaruhi besarnya protein yang dikonsumsi, palatabilitas, kapasitas alat pencernaan serta kemampuan menggunakan 
zat-zat makanan yang diserap merupakan faktor yang ikut menentukan tingkat konsumsi. Ransum yang sama kandungan zat-zat makanannya belum tentu sama pengaruhnya terhadap ternak karena dipengaruhi oleh kesukaan dan pencernaan masing-masing ransum. Palatabilitas bahan pakan akan mempengaruhi konsumsi konsentrat dalam bentuk protein kasar.

\section{Pertambahan Berat Badan Ternak}

Pertambahan berat badan (PBB) merupakan salah satu peubah yang digunakan untuk menilai kualitas pakan ternak. Menurut McDonald et al (2002) pertumbuhan ternak ditandai dengan peningkatan berat dan adanya perkembangan. Pengukuran berat badan berguna untuk menentukan tingkat konsumsi efisiensi pakan dan harga (Parakkasi, 1999). Rata-rata pertambahan berat badan kambing selama penelitian untuk perlakuan P1, P2, P3, dan P4 berturut-turut sebesar 70, 60, 60, dan 40 gram/ekor/hari. Berdasarkan analisis ragam (anova), menunjukkan bahwa perlakuan penggunaan konsentrat berpengaruh tidak nyata $(\mathrm{P}>0,05)$ terhadap pertambahan bobot badan kambing. Hal ini diduga karena konsumsi BK total dan konsumsi PK total berbeda tidak nyata, walaupun konsumsi konsentratnya berbeda, yang mana bungkil inti sawit dikonsumsi lebih sedikit dibandingkan ampas tahu. Hasnudi dan Wahyuni (2005) melaporkan bahwa PBB yang tidak berbeda nyata dapat juga disebabkan oleh ternak yang mengkonsumsi pakan yang jumlahnya tidak berbeda nyata. Menurut Tomaszewska et al. (1993) bahwa laju PBB dipengaruhi oleh umur, lingkungan, dan genetik yaitu berat tubuh fase awal pertumbuhan berhubungan dengan berat dewasa adalah satu kriteria yang digunakan untuk mengukur pertumbuhan adalah dengan pengukuran berat badan. Pertambahan berat badan adalah kemampuan ternak untuk mengubah zat-zat nutrisi yang terdapat dalam pakan menjadi daging. Pertumbuhan juga didefinisikan sebagai perubahan ukuran yang meliputi perubahan berat hidup, bentuk dimensi linier dan komposisi tubuh termasuk perubahan organ-organ dan jaringan tersebut (Suparno, 1994). Pertumbuhan sangat dipengaruhi oleh kualitas dan kuantitas ransum yang diberikan.

Pada hasil diatas menunjukkan bahwa pertambahan berat badan untuk semua perlakuan relatif sama. Kondisi ini menunjukkan bahwa zat makanan yang dikonsumsi dapat digunakan ternak untuk pertumbuhan jaringan yang ditunjukkan dengan adanya pertumbuhan peningkatan berat badan kambing, namun masih jauh lebih rendah jika dibandingkan dengan peningkatan berat badan harian berdasarkan Kearl (1982) sebesar 100 gram/ekor/hari.

Cheeke (1999) menyatakan kualitas dan kuantitas pakan mempengaruhi pertambahan bobot tubuh. Pakan yang cukup kandungan protein dan strukturnya lebih halus akan lebih cepat tercerna oleh mikroba rumen, sehingga laju pencernaan makanan di dalam rumen akan lebih cepat pula dan dapat meningkatkan jumlah konsumsi pakan sehingga mempunyai efek 
positif terhadap pertumbuhan (Martawidjaja et al., 1986).

Bandini (1997), menyebutkan bahwa pertambahan berat badan yang rendah selain disebabkan oleh faktor pakan juga pengaruh genetik (keturunan) dan lingkungan. Terpenuhinya konsumsi bahan kering untuk kebutuhan hidup pokok dan produksi berakibat pada tampilan produksi yang baik pada ternak.

\section{KESIMPULAN}

Penggunaan konsentrat bungkil inti sawit dapat menggantikan ampas tahu dalam ransum tanpa berdampak negatif terhadap pertumbuhan kambing Nubian. Lebih lanjut, penggunaan bungkil inti sawit saja, tanpa penambahan minyak sawit untuk dosing defaunasi ataupun difermentasi merupakan suatu pilihan, mengingat hasil pertambahan berat badan yang sama.

\section{UCAPAN TERIMAKASIH}

Penulis mengucapkan terimakasih kepada PT. Indofood Sukses Makmur, Tbk yang telah mendanai penelitian ini dalam rangka program Indofood Riset Nugraha 2016.

\section{DAFTAR PUSTAKA}

Astuti, M. 2007. Pengantar Ilmu Statisik Untuk Peternakan dan Kesehatan Hewan. Bintang Publisher. Bogor

Bandini, Y. 1997. Sapi Bali. Penebar Swadaya. Jakarta.

Chanjula, P., A. Mesang, and S. Pongprayoon. 2010. Effects of dietary inclusion of palm kernel cake on nutrient utilization, rumen fermentation characteristics and microbial populations of goats fed Paspalum plicatulum hay-based diet. Songklanakarin J Sci Technol. 32:527536.

Cheeke, P. R. 1999. Applied Animal Nutrition : Feed and Feeding. 2 Ed. Prentice Hall, Upper Saddle River, New Jersey.

Davis, J. 2002. Utilisation of Low Quality Roughages for Ruminant Feeding. Proceedings: The $3^{\text {rd }}$ International Seminar on Tropical Animal Production, Gadjah Mada University. Yogyakarta.15-16 Oct. 2002.

Isnainiyati, N. 2001. Penggunaan Jerami Padi Fermentasi dan Kombinasi Jerami Padi Silase Rumput Raja Sebagai Pakan Basal Serta Pengaruhnya Terhadap Pertambahan Bobot Badan Harian dan Kualitas Daging Sapi Peternakan Ongole. Program Pascasarjana Ilmu Peternakan, Fakultas Peternakan,Universitas Gadjah Mada, Yogyakarta.

Kearl. L. C. 1982. Nutrient Requirements of Ruminants in Developing Countries. Agriculture Experimentation Utah State University Logan Utah.

Martawidjaja. M., A. Wilson dan B. Sudaryanto, 1986. Suplementasi Gaplek Dalam Ransum Yang Menggunakan Rumput Gajah dan Bungkil Biji Kapuk Untuk Pertumbuhan Domba. J. Ilmu dan Peternakan 4 (3): 303-306. 
McDonald, P., R.A. Edwards, J.F.D. Greenhalgh dan C.A. Morgan. 2002. Animal Nutrition. $6^{\text {th }}$ Ed. Ashford Colour Pr. Gosfort

Mirnawati, Y. Rizal, Y. Marlida dan I. P. Kompiang, 2013. Evaluation of palm kernel cake fermentted by Aspergillus niger as substitute for soybean meal protein in the diet of broiler. International Journal of Poultry Science. 10 (7): 537-541.

Murtisari, T. 2005. Pemanfaatan limbah pertanian sebagai pakan penunjang agribisnis kelinci. Lokakarya nasional petensi dan peluang penegembangan usaha kelinci. Balai Penelitian Ternak Bogor. Hal: 41-54.

Parakkasi, A. 1999. Ilmu Nutrisi dan Makanan Ternak Ruminan. Indonesia University Press. Jakarta.

Pond, W. G., D. C. Church dan K. R. Pond. 1995. Basic Animal Nutrition and Feeding. $4^{\text {rd }}$ Ed. John Wiley and Sons, Inc., Canada.

Soeparno. 1994. Ilmu dan Teknologi Daging. Gajah Mada University Press, Yogyakarta.
Supriyati and B. Haryanto. 2015. Molasses Protected Palm Kernel Cake As Source of Protein for Young Male Ettawah Grade Goats. JITV 16 (1): 17-24.

Tomaszewska, M. W., I. M. Manika, A. Djajanegara, S. Gardiner dan T.R Wiradarya. 1993. Produksi Kambing dan Domba di Indonesia. Sebelas Maret University Press, Surakarta.

Wijianto, G.A. 2016. Pengaruh Pemberian Ransum Berbasis Limbah Kelapa Sawit terhadap Kadar Amonia dan Volatile Fatty Acid Pada Cairan Rumen Sapi Peranakan Ongole. Skripsi. Jurusan Peternakan Fakultas Pertanian Universitas Lampung. Bandar Lampung

Zarei, M., A. Ebrahimpour, A. AbdulHamid, F. Anwar and N. Saari. 2012. Production of defatted palm kernel cake protein hydrolysate as a valuable source of natural antioxidants. International Journal of Molecular Sciences. 13 (7) : 80978111. 